\title{
When DNA gets in the way in RNA-seq experiments, a
}

2

3

4

6

7 Using a newly developed method dubbed SILVER-Seq-enabling extracellular RNA

\section{sequel}

sequencing (exRNA-seq) directly from a small volume of human serum or plasmaYan et al. recently reported in Current Biology a potential exRNA biomarker for the early diagnosis of Alzheimer's disease [1]. After the publication of the initial paper describing the SILVER-Seq method [2], we reported our concern regarding potential DNA contamination in their datasets [3]. Although the authors replied they were able to successfully treat RNA samples with DNase to avoid such contamination, they did not address our observations of the majority of reads without evidence of being derived from RNA, nor documented verified absence of DNA after DNase treatment [4]. To assess whether the newly data generated may suffer from DNA contamination, we downloaded the publicly available sequencing data and evaluated two quality control metrics (i.e., fraction of exonic and splice reads), which were not reported in the paper. We found that both quality metrics were much lower than expected for RNA-seq data (6.28\% exonic and $0.478 \%$ splice reads), in line with our previous findings on the first SILVER-Seq paper. These observations suggest the data and results presented by Yan et al. are affected by DNA contamination, an issue that may be inherent to the SILVER-Seq technology.

\footnotetext{
${ }^{a}$ Department of Biomolecular Medicine, Ghent University, 9000 Ghent, Belgium; ${ }^{b}$ OncoRNALab, Cancer Research Institute Ghent, 9000 Ghent, Belgium;

${ }^{c}$ Digestive Diseases Unit, Virgen del Rocio University Hospital, 41013 Seville, Spain;

${ }^{d}$ OncoDigest Group, Institute of Biomedicine of Seville (IBiS), 41013 Seville, Spain;

*Correspondence: jasper.verwilt@ugent.be; mdgiraldez-ibis@us.es

$\$$ shared $1^{\text {st }}$ authors
} 
25 RNA sequencing (RNA-seq) has transformed transcriptome characterization in a 26 wide range of biological contexts and is increasingly used to study samples with a 27 Iow RNA concentration, such as human biofluids. Biofluids contain microRNA and 28 other types of sncRNA, fragments of multiple RNA classes (e.g., mRNA, IncRNA, 29 tRNA, mtRNA) and circular RNA [5]. The presence of a variety of exRNA molecules 30 in the human bloodstream and other biofluids has opened up new avenues for the 31 development of minimally invasive biomarkers for a wide range of diseases. 32 However, the explosion in exRNA research has resulted in a growing field lacking standardized protocols, consensus on data analysis, consistent findings and sufficient experimental detail in many publications, which prevents researchers from critically evaluating the quality of the presented results or reproducing the experiments. Besides, performing exRNA-seq experiments without adequate quality 37 controls may result in several issues, one being sample contamination [6].

39 RNA-seq contaminants can be either external (originating from a different sample or another species) or, although often overlooked, internal (originating from other

41 molecules from the same sample). Endogenous DNA contamination can be 42 particularly troubling as it can be hard to detect unless specific quality control 43 measurements are performed. RNA-seq experiments suffering from DNA 44 contamination can lead to biased results as it affects proper data quantification and 45 normalization. Due to the low concentration of RNA in human biofluids, DNA 46 contamination can be particularly vexing in exRNA-seq, preventing the reliable 47 detection of potential biomarkers. 
49 DNase treatment is included in most standardized RNA-seq protocols but, in some

50 instances, it is not completely effective (not all DNA is removed) and can result in

51 impaired final libraries. This problem can be aggravated in protocols using crude

52 biofluids without RNA purification, which may contain DNase-inhibiting molecules

53 (one of them being actin, which has long been known for inhibiting DNase activity

54 [7]). Serum in particular contains not only cell-free DNA but also genomic DNA that

55 originates from lysis of white blood cells during ex vivo clotting [8], thus increasing

56 the risk of DNA contamination in RNA-seq experiments.

57

58 To evaluate whether the RNA-seq signal in the paper by Yan et al. [1] might be 59 affected by contaminating DNA, we replicated the pipeline used in the paper as 60 accurately as possible (no details were reported regarding parameters of sequencing 61 and data analysis) and calculated several quality control metrics. A step-by-step 62 overview of the used tools can be found in the Supplemental Methods section and 63 the full code is uploaded to GitHub

64 (https://github.com/jasperverwilt/exRNA_contamination).

65

66 In order to confirm, or refute, our suspicions, we were mainly interested in two data 67 quality metrics: the fraction of exonic reads ( $5 \%$ in case of sequencing pure DNA) 68 and the fraction of splice reads ( $0 \%$ in case of DNA). Considering all samples, we 69 observe exonic fractions ranging from $4.7 \%$ to $25.4 \%$, with a median value of $6.28 \%$ 70 (Figure $1 \mathrm{~A}$ ); and splice fractions ranging from $0.206 \%$ to $1.27 \%$, with a median value 71 of $0.478 \%$ (Figure $1 \mathrm{~B}$ ). In addition to the splice and exonic fractions, we checked the 72 strandedness of the data. If SILVER-Seq would employ a stranded library 73 preparation approach (which we do not know for sure, as it is unreported), and the 
74 data turns out to be unstranded, contaminating DNA might be at play (since DNA is

75 double stranded, the reads can originate from both strands). With a strandedness of

$76100 \%$ for perfectly stranded data, and $50 \%$ for pure DNA, the observed median

77 strandedness was $49.2 \%$, with individual values ranging from 47.9 to $70.4 \%$

78 (Supplemental Figure 1). These results support the hypothesis of DNA

79 contamination.

80

81 The low median value of exonic and spliced reads prompts us to conclude that most

82 of the SILVER-Seq data generated by Yan et al. is affected by DNA contamination.

83 We deduct that SILVER-Seq is a stranded library prep method, given that some

84 samples showed a strandedness higher than $50 \%$. The wide ranges of the exonic

85 and splice read fractions and variable strandedness level indicate that DNA is

86 differentially present in the samples, with some samples performing consistently

87 worse or better for all quality metrics: SRR10015490, for example, showed relatively

88 high values for all the metrics (Figure 1, Supplemental Figure 1).

89

90 Finally, the biogenesis of exRNA is not well established yet and some authors argue

91 that biofluids might be enriched in intron and antisense sequences compared with

92 cellular RNAs [9]. However, we are concerned that DNA contamination is the most

93 likely explanation here as: (a) some exRNA-seq studies have consistently reported a

94 high proportion of exonic reads and adequate strandedness [10]; (b) the inherent 95 challenge of avoiding DNA contamination, especially when working with crude 96 biosamples as input; and, (c) the high variability of the evaluated quality control

97 metrics across the reported samples. We would like to emphasize that our 98 observations do not undermine the potential utility of SILVER-Seq. Our letter is a call 
bioRxiv preprint doi: https://doi.org/10.1101/2020.09.28.316265; this version posted September 29, 2020. The copyright holder for this preprint (which was not certified by peer review) is the author/funder, who has granted bioRxiv a license to display the preprint in perpetuity. It is made available under aCC-BY-NC 4.0 International license.

99 for thorough reporting of methodology and analysis details including quality control

100 metrics in exRNA-seq studies. We hope that our plea helps to move the exRNA field

101 forward by promoting consistency among laboratories and increasing experimental

102 transparency and reproducibility.

103 


\section{References}

105

106 1. Yan, Z., Zhou, Z., Wu, Q., Chen, Z.B., Koo, E.H., and Zhong, S. (2020).

107 Presymptomatic Increase of an Extracellular RNA in Blood Plasma Associates

108 with the Development of Alzheimer's Disease. Curr. Biol. 30, 1771-1782.e3.

109 Available at: https://doi.org/10.1016/j.cub.2020.02.084 [Accessed September

$110 \quad 16,2020]$

111 2. Zhou, Z., Wu, Q., Yan, Z., Zheng, H., Chen, C.-J., Liu, Y., Qi, Z., Calandrelli,

112 R., Chen, Z., Chien, S., et al. (2019). Extracellular RNA in a single droplet of

113 human serum reflects physiologic and disease states. Proc. Natl. Acad. Sci.

$114 \quad 116,19200-19208$.

115 3. Verwilt, J., Trypsteen, W., Van Paemel, R., De Preter, K., Giraldez, M.D.,

116 Mestdagh, P., and Vandesompele, J. (2020). When DNA gets in the way: A

117 cautionary note for DNA contamination in extracellular RNA-seq studies. Proc.

118 Natl. Acad. Sci. 117, 18934-18936. Available at:

119 http://www.pnas.org/lookup/doi/10.1073/pnas.2001675117 [Accessed August

$12026,2020]$.

121 4. Zhou, Z., Wu, Q., Yan, Z., Zheng, H., Chen, C.J., Liu, Y., Qi, Z., Calandrelli, R.,

122 Chen, Z., Chien, S., et al. (2020). Reply to Verwilt et al.: Experimental evidence

123 against DNA contamination in SILVER-seq. Proc. Natl. Acad. Sci. U. S. A. 117,

124 18937-18938. Available at: www.pnas.org/cgi/doi/10.1073/pnas.2008585117

$125 \quad$ [Accessed August 26, 2020].

126 5. Hulstaert, E., Morlion, A., Cobos, F.A., Verniers, K., Nuytens, J., Eynde, E.

127 Vanden, Yigit, N., Anckaert, J., Geerts, A., Hindryckx, P., et al. (2019). Charting

128 extracellular transcriptomes in The Human Biofluid RNA Atlas. bioRxiv, 
823369.

130 6. Nieuwenhuis, T.O., Yang, S.Y., Verma, R.X., Pillalamarri, V., Arking, D.E., Rosenberg, A.Z., McCall, M.N., and Halushka, M.K. (2020). Consistent RNA sequencing contamination in GTEx and other data sets. Nat. Commun. 11,110. Available at: https://doi.org/10.1038/s41467-020-15821-9 [Accessed

$134 \quad$ September 17, 2020].

135 7. Blikstad, I., Markey, F., Carlsson, L., Persson, T., and Lindberg, U. (1978). Selective assay of monomeric and filamentous actin in cell extracts, using inhibition of deoxyribonuclease I. Cell 15, 935-943. Available at: http://www.cell.com/article/0092867478902775/fulltext [Accessed September 17, 2020].

8. Lee, T.H., Montalvo, L., Chrebtow, V., and Busch, M.P. (2001). Quantitation of genomic DNA in plasma and serum samples: Higher concentrations of genomic DNA found in serum than in plasma. Transfusion 41, 276-282. Available at: https://onlinelibrary.wiley.com/doi/full/10.1046/j.15372995.2001.41020276.x [Accessed September 17, 2020].

9. Qin, Y., Yao, J., Wu, D.C., Nottingham, R.M., Mohr, S., Hunicke-Smith, S., and Lambowitz, A.M. (2016). High-throughput sequencing of human plasma RNA by using thermostable group II intron reverse transcriptases. RNA 22, 111128. Available at: http://www.rnajournal.org/cgi/doi/10.1261/rna.054809.115.

150 10. Everaert, C., Helsmoortel, H., Decock, A., Hulstaert, E., Van Paemel, R., Verniers, K., Nuytens, J., Anckaert, J., Nijs, N., Tulkens, J., et al. (2019). 
bioRxiv preprint doi: https://doi.org/10.1101/2020.09.28.316265; this version posted September 29, 2020. The copyright holder for this preprint (which was not certified by peer review) is the author/funder, who has granted bioRxiv a license to display the preprint in perpetuity. It is made available under aCC-BY-NC 4.0 International license.

154 http://www.nature.com/articles/s41598-019-53892-x [Accessed January 20,

155 2020].

156

157

158 


\section{Figures}

160

\section{Figure 1}

162

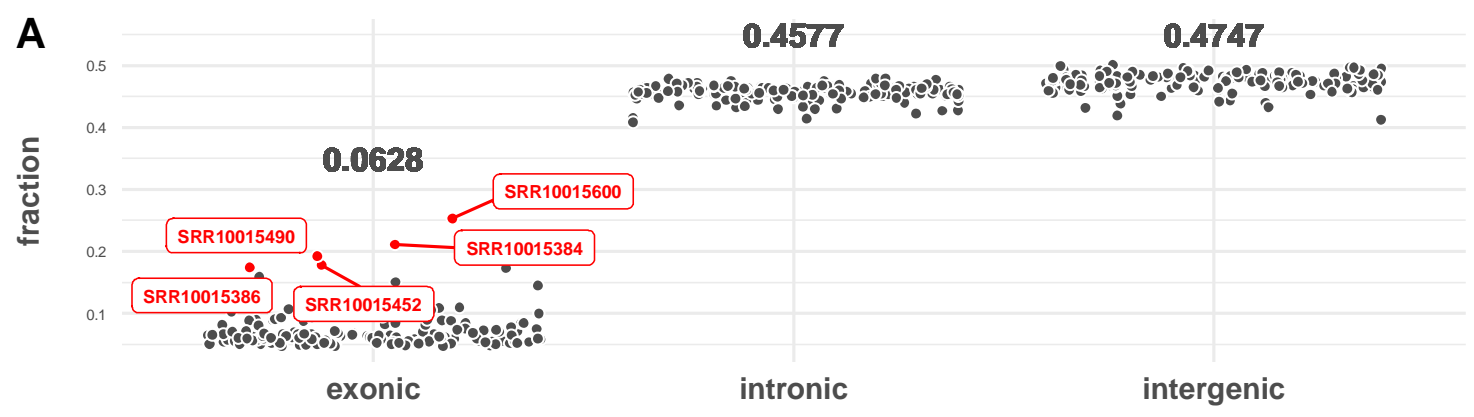

B $\quad 0.9952$

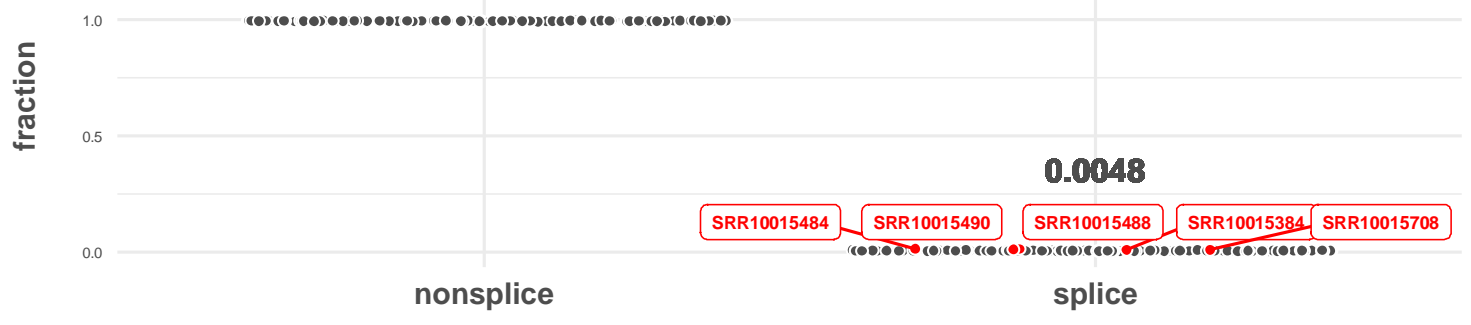

163

164

\section{Figure legends}

166

167 Figure 1: Regional coverage and splice read fractions of the data. (A) Fractions of

168 reads mapping to exonic, intronic and intergenic regions. The data points are

169 calculated values for individual samples. The median fractions over all samples are

170 printed. The five samples with the highest exonic coverage are annotated and

171 colored red. (B) Fractions of reads mapping to splice and nonsplice regions. The data

172 points are calculated values for individual samples. The median fractions over all 
bioRxiv preprint doi: https://doi.org/10.1101/2020.09.28.316265; this version posted September 29, 2020. The copyright holder for this preprint (which was not certified by peer review) is the author/funder, who has granted bioRxiv a license to display the preprint in perpetuity. It is made available under aCC-BY-NC 4.0 International license.

173 samples are printed. The five samples with the highest fraction of reads mapping to

174 splice junctions are annotated and colored red.

175

176 